\title{
ACTS OF ASSEMBLY
}

FAIRMOUNT PARK.

PHIL A DELPHIA :

KING \& BAIRD, PRINTERS, No. 607 SANSOM STREET.

1868 



\section{ACTS OF ASSEMBLY}

REIATING TO

\section{FAIRMOUNT PARK.}

Pa. Laws, stat utes, etc.

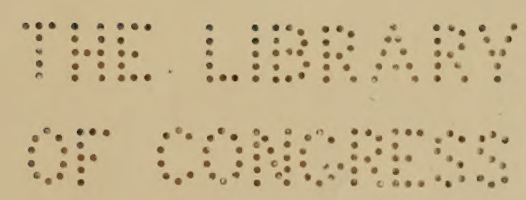

PHILA DEL PHIA :

KING \& BAIRD, PRINTERS, No.607 SANSOM STREET.

1868 . 


$$
\operatorname{sos}^{x^{x^{6^{3}}}} p^{s^{5^{x}}}
$$

\section{JAN 191905
$D_{1}$ of $D_{1}$}

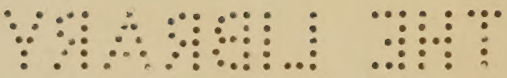

$$
\begin{aligned}
& \text { ओओ }
\end{aligned}
$$




\section{AN ACT}

Appropriating ground for public purposes in the City of Philadelphia.

SEC. 1. Be it enacted by the Senate and House of Representatives of the Commonwealth of Pennsylvania, in General Assembly met, and it is hereby enacted by the authority of the same, That the title to and ownership of the area of ground which is bounded as follows, beginning at a point on the river Schuylkill at the intersection of the north line of Bridge street and low water mark in said river, thence along said north line of Bridge street to Bridgewater street, thence along the easterly side of Bridgewater street to the north line of Haverford street as now used, thence along the northeast line of said Haverford street to the Pennsylvania Railroad, thence along the said Pennsylvania Railroad to the Junction Railroad, thence along the said Junction Railroad, its several courses and distances, to a point where it intersects Girard avenue, thence westwardly along the north line of Girard avenue to Forty-first street, thence northward along Forty-first street to Lansdowne avenue, thence along said Lansdowne avenue westwardly to Belmont avenue, thence along said Belmont avenue northwardly to Montgomery avenue, thence eastwardly along said Montgomery avenue in a direct line to the water line of Fairmount dam, thence down the river Schuylkill along the low water line thereof to the place of beginning, excepting therefrom and thereout that part of which the Schuylkill Navigation, the Pennsylvania Central, the Junction and the Connecting Railroad Companies are respectively seized for the execution of their franchises, shall be vested in the City of Philadelphia, 
to be laid out and maintained forever as an open public place and park for the health and enjoyment of the people of said city, and the preservation of the purity of the water supply of the city of Philadelphia.

Sec. 2. That the Mayor, the Presidents of the Select and Common Councils, Commissioner of City Property, the Chief Engineer and Surveyor, and the Chief Engineer of the Water Works of said city, together with ten citizens of said city, who shall be appointed for five years, five of whom by the District Court, and five of whom by the Court of Common Pleas of said city, be and the same are hereby constituted Commissioners of said park; they shall organize annually, on the first Monday of June, by the election of a president and secretary, but they shall receive no compensation for their services as commissioners. Provided that whenever a vacancy shall occur in that part of the said commissioners appointed by the courts, the court from which the appointment was made shall fill the vacancy.

Sec. 3. That the owners of the said ground by the first section of this act appropriated for public purposes, shall be paid for the same by the City of Philadelphia, according to the value which shall be ascertained by a jury of twelve disinterested freeholders to be appointed by the Court of Quarter Sessions of said city, upon the petition of said commissioners; and if the said commissioners shall delay petitioning as aforesaid for the period of sixty days after notice given of their taking possession of said ground, then said jury shall be appointed upon the petition of any person whose property shall be so taken. Provided, however, that in any case the said commissioners may negotiate and agree with the owners of any part of said ground as to the price thereof, and said price shall be reported to the said Court of Quarter Sessions, and if confirmed and approved 
by said court, shall be conclusive upon said city. And provided further, that whenever it shall be necessary to have recourse to a jury to assess the damages for any property to be taken as aforesaid, the said jury shall estimate the advantage to property adjoining or in the vicinity, and said jury shall proceed and their award shall be reviewed and enforced in the same manner as provided by law in the opening of roads in the city of Philadelphia.

SEc. 4. That the commissioners of said park, after they shall have secured possession of the ground, shall adopt a plan for the improvement and maintenance thereof, and shall have powers to proceed with the same, and all moneys expended shall be under their supervision, but no contracts shall be made for said improvement unless an appropriation therefor shall have been first made by the Councils of said city.

SEc. 5. That as soon as the said commissioners shall have fully organized, they shall have the care and management of Fairmount park on both sides of the river Schuylkill, and all plans and expenditures for the improvement and maintenance of the same shall be under their control, subject to such appropriations as Councils may from time to time make as aforesaid.

SEc. 6. That the commissioners of said park are hereby further empowered, whenever the Councils of the city of Philadelphia shall so declare by ordinance, to take such other land as may be deemed proper by said Councils for the extension of said Fairmount park, between the Spring Garden Water Works and the Columbia bridge and between the Reading Railroad and the river Schuylkill, according to the value which shall be ascertained by a jury 
of twelve disinterested freeholders, to be appointed by the Court of Quarter Sessions of said city upon the petition of said commissioners; and if the said commissioners shall delay petitioning as aforesaid for a period of sixty days after notice given of their taking possession of said ground, then said jury shall be appointed upon the petition of any person whose property shall be so taken. Provided, however, that in any case the said commissioners may negotiate directly and agree with the owners of any part of said ground as to the price thereof, and said price shall be reported to the said Court of Quarter Sessions, and if confirmed or approved by said court, shall be conclusive upon said city; and provided further, that whenever it shall be necessary to have recourse to a jury to assess the damages for any property to be taken as aforesaid, the said jury shall estimate the advantage to property adjoining or in the vicinity, and said jury shall proceed, and their award shall be reviewed and enforced in the same manner as provided by law in the opening of roads in the city of Philadelphia.

Approved March 26, $186 \%$ 


\section{A SUPPLEMENT}

To an Act, entitled "An Act appropriating ground for public purposes, in the City of Philadelphia," approved the twenty-sixth day of March, Anno Domini one thousand eight hundred and sixty-seren.

Section 1. Be it enacted by the Senate and House of Representatives of the Commonwealth of Pennsylvania in General Assembly met, and it is hereby enacted by the authority of the same, That the boundaries of the Fairmount Park in the City of Philadelphia shall be the following, to wit: Beginning at a point in the northeasterly line of property owned and occupied by the Reading Railroad Company, near the City bridge over the river Schuylkill at the Falls, where said northeasterly line is intersected by the line dividing property of $\mathrm{H}$. Duhring from that of $\mathrm{F}$. Stoever and T. Johnson; extending from thence in a southwesterly direction upon said dividing line and its prolongation to the middle of the Ford road; from thence by a line passing through the southeast corner of Forty-ninth and Lebanon streets to George's run; thence along the several courses of said run to a point fourteen hundred and eighty-seven and a half feet from the middle of the Pennsylvania Railroad, measured at right angles thereto; thence by a straight line through the northeast corner of Forty-third and Hancock streets to the northerly side of Girard avenue near Fortieth street; thence by the said northerly line of Girard avenue to the easterly side of the Junction Railroad as now used; thence by the said easterly side of the Junction Railroad and the Pennsylvania Ricil- 
road to the north side of Haverford street; thence by the northerly side of said Haverford street to the westerly side of Bridgewater street; thence by said Bridgewater street to the north line of Bridge street; thence by said Bridge street to the west abutment of the Suspension bridge; thence by the northwesterly side of the Suspension bridge and Callowhill street to the angle in said street, on the southwesterly side of Fairmount basin; thence by the northerly side of Callowhill and Biddle streets to the westerly side of Twenty-fifth street; thence by the said Twenty-fifth street to the southwesterly side of Pennsylvania avenue; thence by the southwesterly side of Pennsylvania avenue to the west side of Thirty-third street; thence along the westerly side of 'Thirtythird street to the southwesterly line of Ridge avenue; thence along said Ridge avenue to the southwesterly line of South Laurel Hill Cemetery, (north of Huntingdon street;) thence by and along said property line to such a distance from the shore line of the river Schuylkill as will permit the location of a carriage road one hundred feet wide upon its margin; thence along said river shore and its several courses as may be most practicable, at the same distance as above specified, (provided said distance shall not exceed one hundred and fifty feet,) to a point opposite the intersection of the Ridge turnpike and School lane; thence northwardly to a point on the southwesterly side of said turnpike road opposite to the southeasterly side of said School lane; thence by the southwesterly side of the Ridge turnpike road and its several courses to the southeasterly side of the Wissahickon creek; thence by the several courses of the said southeasterly side of Wissahickon creek to the Schuylkill river; thence across the water course of said river to the northeasterly line of the Reading Railroad Company's property 
as now occupied and in use, at the City boundary line: thence along said northeasterly line, as now occupied and used by said railroad company, to the place of beginning : excepting, nevertheless, thereout the several Wrater Works and their appurtenances, which are included within these boundaries, and such uses of the premises immediately adjacent to the same, and such other portions of the ground as are described in this section, as the City of Philadelphia may from time to time require for the purposes of its water department.

SEc. 2. That there shall be laid out and constructed a road of easy and practicable grades extending from the intersection of the northerly line of the Park by Belmont arenue on the westerly sicle of the river Schuylkill to the head of Roberts' Hollow, and thence along said hollow and the river Schuylkill to the foot of City avenue, laid out with the ground contiguous thereto for ornamentation, of such width and so constructed as the Commissioners of Fairmount park appointed under authority of the act of the General Assembly of the Commonwealth may determine. And such road and its contiguous ground are hereby declared to be a part of the aforesaid park; and said Park Commissioners are hereby anthorized and required to ascertain, by a proper survey, the limits thereof, which survey they shall file in the survey department of the city of Philadelphia. And it shall also be the duty of said Park Commissioners to appropriate the shores of the Wissahickon creek on both sides of the same from its mouth to the Paul's Mill road, and of such width as may embrace the road now passing along the same; and may also protect the purity of the water of said creek, and by passing along the crest of the heights which are on either side of said creek, may preserve the beauty of its scenery. The said Park Commissioners are hereby authorized and 
required to cause a proper survey to be made of said grounds upon the TVissahickon, and to file said survey in the Survey Department of the city of Philadelphia, and the grounds and creck hereby appropriated are declared to be a part of Fairmount park.

SEC. 3. That the title to and ownership of the ground within said boundaries shall be vested in the City of Philadelphia, excepting therefrom so much as shall be required by the Schuylkill Narigation Company, the Philadelphia and Reading, the Junction and Connecting Railroad Companics for the exccution of their franchises as now provided by law.

SEC. 4. So much of the ground as was embraced in the Act to which this is a Supplement, approved the twenty-sixth day of March, one thousand eight hmolred and ixty-seven, and is not inclurled in the above boundaries, is hereby released from all claim of title by the said city, with the same effect as if it had never been included.

SEC. 5. That all the grounds taken within the boundarics of the Faimount Park by the first sections of this 1ct, shall be subject to all the powers and control given by the Act to which this is a Supplement to the City of Philadelphia and the Park Commissioners designated by or appointed under said Act; and the owners of all ground taken for the Park, and others interested therein, shall be compensated as in said Act is directed and provided.

SEC. 6. The said Commissioners shall have power and authority, from time to time, to vacate any street or road within the boundaries of the Park, (excepting Girard avemue, and to open for public use such other roads, avenues and streets therein as they deem necessary.

SE. 7. The Councils of the City of Philadelphia shall cause, un:ler the supervision of the Department of Surveys, 
such alterations of the plan of survey of the Twenty-fourth Ward as lies between Fairmount Park as by this Act established, the Pennsylvania Railroad and the City avenue, and of the contiguous parts of the Twenticth and Twentyeighth Wards, as may become necessary or expedient by reason of the extension as aforesaid of the limits of the Fairmount Park, and canse the same to be established in manner as now provided by law for revising or laying out plans of survey in and for the City of Philadelphia; and shall lay out an avenue as one of the streets of the city, of the width of not less than one hundred feet, as a boundary of the Park on the southwest, west and northwest sides thereof, extending from Girard avenue to the river Schuylkill, at or near the Falls bridge; and also upon the enstern side of the river from the intersection of Pennsylvania arenue and Thirty-third strect, northward along the boundary of said Park to the river Schuylkill.

SFC. 8. The jurisdiction of the Commissioners of the Park shall extend to the breadth of the footway next the Park, in all avenues or streets which shall bound upon the Park, and they shall direct the manner in which such footways shall be laid out, curbed, pared, planted and ornamented; which footways shall not be less than twenty fect in width on any avenue or street of the wilth of one hundrecl feet, and of like proportion upon any street or arenue of a greater or less width, unless otherwise directed by the Commissioners.

SEC. 9. The said Park Commissioners or jury who shall assess the compensation to the owners for the ground taken, shall ascertain and make compensation for buildings, as well as the ground taken; but all buildings and machinery and fixtures not required by the Park Commission, shall be renored by the owners thereof whenever payment of the compensation awarded them 
shall be made or tendered to them; and upon such payment or tender, the Park Commissioners shall forthwith take possession of the premises. If any owner or lessee of ground taken cannot be found, notice of the taking and valuation of his land shall be given by advertisement in two daily papers, published in Philadelphia, six times, and in the Legal Intelligencer twice; and the amount arvarded in such case to the owner or lessee, shall remain in the City treasury, until such owner shall produce the decree of the court having jurisdiction in the premises, ordering the said moneys to be paid to him or his legal representatives.

Sec. 10. The said Commissioners and jury may make partial or special reports, from time to time, to the court, as they may be ready to do so, and the court may act upon such reports separately; and the powers of the jury shall continuc, unless limited by the court, or they be required by the court to make report, until they shall have reported on all the cases on which they have been appointed, although a term or terms of the court shall have intervened; and jurors, not to exceed six in number, may be appointed upon one or more cases, according to the order of the court made; and whenever any report of the said Commissioners or of the jury shall have been confirmed by the court, the valuition made shall be forthwith payable by the City of Philadelphia.

SEc. 11. The City of Philadelphia shall be authorized and required to raise by loans, from time to time, such sums of money as shall be necessary to make compensation for all grounds heretofore taken or to be taken for said Fairmount Park, and for the laying out and construction thereof for public use; for the permanent care and improvement thereof, and for all culverts and other means of preserving the Schuyllill water pure for the use of the citizens of said 
city; and shall ammally assess taxes for kceping in repair and good order the said Park; and shall also provide for the payment of the interest on all said loaus, and the numal sinking fund for the redemption thereof.

$\mathrm{S}=\mathrm{c} .12$. The said Park Commissioners shall, from time to time, appoint such officers, agents and subordinates as they may deem necessary, for the purposes of this Act and the Act to which this is a Supplement; and they shall prescribe the duties and the compensation to be paid them; and so much of the second section of the Act to which this is a Supplement, as requires that the Secretary shall be cliosen from the Commissioners, be and the same is hereby repealed.

SEc. 13. It shall be lawful for said Park Commissioners to acquire title to the whole of any tract of land, part of which shall fall within the boundaries mentioned in the first sections of this Act, and to take conveyance there of in the name of the City of Philadelphia ; and such part thereof as shall lie beyond or within the said Park limits, again to scll and convey in absolute fee simple to any purchiaser or purchasers thereof, by deeds to be signed by the Mayor, under the seal of the City, to be affixed by direction of Coumcils; either for cash, or part cash and part to be secured by bond and mortgrage to the (ity, paring all cash into the City treasury: Provided, that the proceeds of such sales shall be paid into the sinking fund for the redemption of the loan created under the provisions of this Act: Provided also, that no Commissioner, nor any officer under the Park Commission, shall in any wise be directly or indirectly interested in any such sale of lands by the Commissioners as aforesaid; and if any Commissioner or officer aforesaid shall act in riolation of this proriso, he shall, if a Commissioner, be subject to expulsion; if an officer, to be discharged, by a majority of votes of the Board of Park 
Commissioners, after an opportunity afforded of explanation and defence.

SEC. 14. The said Board of Commissioners shall annually hereafter, in the month of December, make to the Mayor of the City of Philadelphia, a report of their proceedings, and a statement of their expenditures for the preceding year.

SEC. 15. The said Park Commissioners shall have exclusive power to lease from year to year, all houses and buildings within the Park limits, which may be let without prejudice to the interests and purposes of the Park, by leases to be signed by their President and Secretary, and to collect the rents and pay them into the City treasury.

SEc. 16. All houses and buildings now built or to be built on any part of the Park grounds, by or for boat or skating clubs, or zoological or other purposes, shall be taken to have rights subordinate to the public purposes intended to be subserved by acquiring and laying out the Park, and shall be subject to the regulations of said Park Commissioners, under licenses which shall be approved by the Commission, and signed by the President and Secretary, and will subject them to their supervision and to removal, or surrender to the City, whensoever the said Commissioners may require.

SEc. 17. The said Park Commissioners shall have power to accept in the name and behalf of the City of Philadelphia, devises, bequests and donations of lands, moneys, objects of art and natural history, maps and books, or other things, upon such trusts as maly be prescribed by the testator or donor; provided such trusts be satisfactory to the Commission, and compatible with the purposes of said Park.

SEC. 18. None of the Park Commissioners, nor any person employed by them, shall have power to create any 


\section{5}

debt or obligation to bind said Board of Commiscioners, except by the express authority of the said Commissioners at a meeting duly convened.

SEc. 19. The said Park Commissioners shall have the power to govern, manage, lay out, plant and ornament the said Fairmount Park, and to maintain the same in good order and repair; and to construct all proper bridges, buildings, railways, and other improvements therein, and to repress all disorders therein under the provisions hereinafter contained.

SEc. 20. That the said Park Commissioners shall have authority to license the laying down, and the use for a term of years, from time to time, of such passenger railways as they may think will comport with the use and enjoyment of the said Park by the public, upon such terms as said Commissioners may agree; all emoluments from which shall be paid into the City treasury.

SEC. 21. The said Park shall be under the following rules and regulations, and such others as the Park Commissioners may from time to time ordain.

I. No persons shall turn cattle, goats, swine or horses or other animals loose into the Park.

II. No persons shall carry fire-arms, or shoot birds in the Park, or within fifty yards thereof, or throw stones or other missiles therein.

III. No one shall cut, break, or in anywise injure or deface the trees, shrubs, plants, turf, or any of the builelings, fences, structures or statuary, or foul any fountains or spiings within the Park.

IV. To person shall drive or ride therein at a rate exceeding seven miles an hour.

V. No one shall ride or drive therein, upon any other than upon the avenues and roads.

VI. No coach or rehicle used for hire, shall stand upon 
any part of the Park for the purpose of hire, nor except in waiting for persons taken by it into the Park, unless in either case at points designated by the Commission.

VII. No wagon or vehicle of burden or traffic shall pass through the Park, except upon such road or avenue as shall be designaterl by the Park Commissioners for burden transportation.

VIII. No street railroad car shall come within the lines of the Park without the license of the Park Commission.

IX. No person shall expose any article for sale within the Park without the previous license of the Park Commission.

X. No person shall take ice from the Schuylkill within the Park without the license of the said Commission first had, upon such terms as they may think proper.

XI. No threatening, abusive, insulting, or indecent language shall be allowed in the Park.

XII. No gaming shall be allowed therein, nor any obscene or indecent act therein.

XIII. No person shall go in to bathe within the Park.

$\mathrm{XIV}$. No person shall fish or disturb the water-fowl in the pool, or any pond, or birds in any part of the Park, nor clischarge any fire-works therein, nor affix any bills or notices therein.

XV. No person shall have any musical, theatrical, or other entertainment therein, without the license of the Park Commissioners.

XVI. No person shall enter or leave the Park except by such gates or avenues as may be for such purpose arranged.

XVII. No gathering or meeting of any kind, asscmbled through advertisement, shall be permitted in the Park without the previous permission of the Commission; nor shall any gathering or meeting for political purposes in the Park be permitted under any circumstances. 
XVIII. That no intoxicating liquors shall be allowed to be sold within said Park.

SEC. 22. Any person who shall riolate any of said rules and regulations, and any others which shall be ordained by the said Park Commissioners, for the government of said Park, not inconsistent with this act, or the laws and constitutions of this State and Uniterl States-the power to ordain which rules and regulations is hereby expressly giren to said Commissioners-shall be guilty of a misdemeanor, and shall pay such fine as may be preseribed by said Park Commissioners, not to exceed five dollins for each and every riolation thereof, to be recovered before any alderman of said ('ity, as debts of that amount are recorcrable, which fines shall be paid into the City treasury: Promted, That if said Park Commissioners should license the taking of ice in said Park, or the entry of any street railroad car therein, or articles for sale, or musical entertainments, it may be with such ecmpensation as they may think proper, to be paid into tlie City treasury; And procided, That any person riolating any of said rules and regulations shall be further liable to the full extent of any damage by him or her committed, in trespass or other action; and any tenant or licensed party who shall violate the said rules, or any of them, or consent to or permit the same to be violated on his or her or their premises, shall forfeit his or her or their lease or license, and shall be liable to be forthwith removed by a rote of the Park Commission; and erery lease and license shall contain a clause making it cause of forfeiture thereof for the lessee or party licensed to riolate or permit or suffer any violation of said rules and regulations or any of them. It shall be the duty of the police appointed to duty in the Park, without warrant, forthwith to arrest any offender against the preceding rules and regulations, whom they may de- 
tect in the commission of such offence, and to take the person or persons so arrested forthwith before a magistrate having competent jurisdiction.

SEC. 23. All rents, license charges and fees; all fines, procecds of all sales, except of lands purchased, and profits of whatsocver kind to be collected, received, or howsoever realized, shall be paid into the City treasury, as a fund to be exclusively appropriated by Councils for Park purposes, under the direction of said Commission: Provided, That moneys or property given or bequeathed to the Park Commissioners upon specified trusts shall be received and receipted for by their 'Treasurer, and held and applied according to the trusts specified.

SEc. 2t. That the Coumcils of the City of Philadelphia be and they are hereby authorized to widen and straighten any street laid upon the prublic plans of said City, as they may think requisite to improve the approaches to Fairmount Park.

SEC. 25. That nothing in this Act contained shall suspend or affect any proceeding pending in court under any existing law; but the same shall be proceeded in as if this Act had not been passed.

SEC 26. The damages for ground and property taken for the purpose of this Act shall be ascertained, adjuster and assessed in like manner as is prescribed by the Act to which this is a supplement.

SEc. 27. The said Park Commissioners shall employ, equip, and pay a Park force, adequate to maintain good order therein and in all houses thereupon; which force shall be subject to the orders of the Mayor upon any emergency; and so far as said force shall consist of others than the hands employed to labor in the Park, it shall be appointed and controlled as the other police of the City. 
SEc. 28. There shall be an additional assistant appointed by the City Solicitor, whose duty it shall be, under the direction of the City Solicitor, to attend to the assessments of damages, and to such other business of a legal nature connected with the Park as said Commissioners may require.

\section{GEO. T. THORN,} Speaker of the House of Representatives.

JAS. L. GRAHAM, Speaker of the Senate.

Approved the fourteenth day of April, Anno Domini one thousand eight hundred and sixty-eight, (A. D. 1868.)

JNO. W. GEARY. 


\section{OfFice of THE \\ Secretary of the Commonwealth, Ha Rrisburg, April 17 th, A. D. 1868.}

Pennsyluania, ss.:

I DO HEREBY CERTIFY, That the foregoing and annexed [SEAL.] is a full, true and correct copy of the original Act of the General Assembly, entitled "A Supplement to an Act entitled 'An Act appropriating ground for public purposes in the City of Philadelphia,' approved the Twenty-sixth day of March, Anno Domini one thousand eight hundred and sixty-seven," as the same remains on file in this office.

IN TESTIMONY WHEREOF, I have hereunto set my hand and caused the seal of the Secretary's Office to be affixed, the day and year above written.

\section{E. JORDAN,}

Secretary of the Commonwealth. 
LIBRARY OF CONGRESS

|| || || || || || || ||||||||||||| |i||||||||||

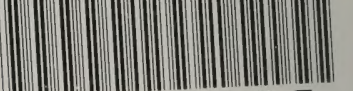

00009116497 